\section{Sexual Differences in Depression in a Brain Tumor Patients}

Nenad Zivkovic ${ }^{1}$, Goran Mihajlovic ${ }^{2,3}$, Marko Markovic ${ }^{1}$, Milan Jovanovic ${ }^{4}$

${ }^{1}$ Department of Neurosurgery, Clinical Hospital Center Zemun, Belgrade, Serbia;

${ }^{2}$ Psychiatry Clinic, Clinical Hospital Center, Kragujevac, Serbia; ${ }^{3}$ University of Kragujevac, Faculty of Medical Sciences, Kragujevac, Serbia;

${ }^{4}$ Department of Otorinolaringology and Neck Surgery, Clinical Hospital Center Zemun, Belgrade, Serbia

\section{Abstract}

Gender differences have been found in many cardiac, stroke and cancer disorders. Sexual differences on depression among brain tumor patients has been rarely studied. The aim of this study was to determine relations between manifested depressive episode and gender in brain tumor patients. The data consisted of 115 patients with a primary brain tumor, 61 males and 54 females. Depression of the patients was assessed by Hamilton Depression Scale (HADS) and functional status by Karnofsky Performance scale (KPS). The level of depression in females was higher compared to that of males. There were no statistically significant differences between male and female groups, although depression is more prevalent in women. Our data are similar to the majority of results from epidemiological studies that show that depression is more prevalent in females. Further studies are needed to find the conection between biological cause of brain tumors anddepression. Sex differences help us to understand the nature of neuropsychiatric disorders, which will help us to find specific treatments and prevention strategies.

Keywords: sexual differences; depression; brain tumors; neuro-oncology;

\section{Razlike u polovima u depresiji kod pacijenata sa tumorom mozga}

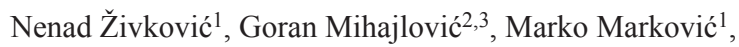 \\ Milan Jovanović ${ }^{4}$ \\ ${ }^{1}$ Odeljenje Neurohirurgije, Kliničko Bolnički Centar Zemun, Beograd, \\ Srbija; \\ ${ }^{2}$ Klinika za Psihijatriju, Kliničko Bolnički Centar Kragujevac, Srbija \\ ${ }^{3}$ Univerzitet u Kragujevcu, Fakultet Medicinskih Nauka, Kragujevac, \\ Srbija; \\ ${ }^{4}$ Odeljenje Otorinolaringologija i hirurgije vrata, Kliničko Bolnički \\ Centar Zemun, Beograd, Srbija
}

\section{Apstrakt}

Razlike u polu su pronađene u mnogim oboljenjima srca, kod moždanog udara i tumora.Razlike u poluu depresiji kod pacijenata satumorommozga su retko istraživane. Cilj rada Cilj ovog rada je bio da se utvrdi odnos između ispoljene depresivne epizode i pola kod pacijenata sa tumorom mozga. Metode rada Podaci se sastoje od 115 pacijenata sa primarnim tumorommozga, 61 muškaraca i 54 žena. Depresija pacijenata je procenjena Hamiltonov skalom depresivnosti (HADS). Nivo depresije kod žena je bila veća u odnosu namuškarce. Nije bilo statistički značajne razlike između muške i ženske grupe, iako je depresija češća kod žena. Naši podaci su slični kao i većina rezultata iz epidemioloških studija koje pokazuju da je depresija češća kod žena.Dalje studije su potrebne da pronađu konekciju između biološkog uzroka tumora mozga i depresije. Razlike u polu pomažu nam da razumemo prirodu neuropsihijatrijskih poremećaja, koje će nam pomoći da pronađemo specifične tretmane i strategije prevencije.

Key words: polne razlike; depresija; tumori mozga; neuro-onkologije;

\title{
Introduction
}

Gender differences have been found in many cardiac, stroke and cancer disorders ${ }^{[1-4]}$. Sex differences and the risks of developing neuropsychiatric disorders are programmed into our brain during early development and do not only show up in the prevalence of disorders, but also in their signs, symptoms and course. Mechanisms of depression in patients with brain tumors have not been fully elucidated. Numerous factors have been examined. Sexual differences on depression among brain tumor patients has been rarely studied $[5,6]$. Some studies have documented higher incidence of depression in female patients compared to male patients. Weitzner et 
al. ${ }^{[7]}$ evaluated a group of 50 patients with primary brain tumors and found that five factors adversely affected QOL, among other things, female gender and poor performance status. Neuroepithelial tumors although more common in men, and meningiomas are more common in women ${ }^{[8,9]}$, the incidence of depression in glial tumors is higher in women. Sintonen et al. ${ }^{[10]}$ found in prospective study among 101 brain tumor patients that females had lower QOL at three measurement points compared to males. Worse QOL among female patients was connected with depression ${ }^{[11]}$.

The aim of our prospective study is to determine gender differences in brain tumor patients.

\section{Materials and Methods}

Population were 115 patients admitted to the Department of Neurosurgery Clinical Hospital Center Zemun who had a brain tumor surgery during 2011 and 2012. The sociodemographic and clinical data was taken at admission and the psychiatrist interviewed the patients. After patients have been introduced with surgery the written consent was also obtained. The study was approved by Ethic committee Clinical Hospital Center Zemun. The patients had referred for surgery and the sampling was done with simple random. All the patients had standard (paraffin) biopsy, confirmed histologic type of tumor by the neuropathologist and the tumors were classified and graded according to WHO classification. Tumors were gathered into groups according to the tumor type (malignancy).

The study entrance criteria:The patients have brain tumor, age ranges between 15-65 years, none had the history of prior psychological and neurological illness or surgery, not being or were treated with chemotherapy or radiotherapy before the surgery.

The excluding criteria were: The patients were not in the mentioned age ranged, had metastatic brain tumor, had a history of psychological and neurological illness or surgery, were treated with chemotherapy and radiotherapy before the surgery.

\section{Clinical measures}

Hamilton scale (HADS):Depressive symptoms were evaluated by the Hamilton depression scale (HADS). HADS is widely used and accepted as a valid screening instrument for depressive symptoms corresponding to diagnostic criteria for depressive disorders followed by DSM-IV diagnostic classification. HADS has been used in earlier studies evaluating depressive symptoms among patients with a primary brain tumor. This test consists of 17 questions that evaluate symptomes of depression. The minimum score is zero and the maximum score is 25 . The scale is graded by an interviewer (psychiatrist). This scale includes a wide range of symptoms that are usually present as the symptoms of a specific state of depression.

Back Scale (BS): The Beck Depression Inventory (BDI, BDI-1A, BDI-II), is a 21-question multiplechoiceself-report inventory, one of the most widely used psychometric tests for measuring the severity of depression. In its current version, the BDI is designed for individuals aged 13 and over, and is composed of items relating to symptoms of depression such as hopelessness and irritability, cognitions such as guilt or feelings of being punished, as well as physical symptoms such as fatigue, weight loss, and lack of interest in sex.

\section{Method of data analysis}

After completing the demographic and Hamilton anxiety questionnaires, the data were entered into the SPSS software and analyzed through descriptive statistical test and Pearson correlation coefficient, stepwise regression, the t- test and one-way ANOVA. 


\section{Results}

Socio-demographic characteristics of the patients with brain tumors were compared by gender, and patients had significant difference in socio-demographic characteristics between the tumor groups only by employment (Table 1).

There is no significant difference between male (54.54) and female (54.59) patients with tumorsconsidering age $(\mathrm{p}>0.005)$. When the Back and Hamilton datas was examined separately for males and females, the results was that there were no significant differences between the tumor groups.

\begin{tabular}{|c|c|c|c|c|}
\hline \multicolumn{2}{|c|}{ Characteristics } & $\begin{array}{l}\text { Males } \\
(n=61)\end{array}$ & $\begin{array}{l}\text { Females } \\
(n=54)\end{array}$ & $\begin{array}{l}\text { Gender } \\
\text { difference } \\
\text { p-value }\end{array}$ \\
\hline \multicolumn{2}{|l|}{ Age (years) } & $54.54 \pm 9.919$ & $54.59 \pm 8.884$ & 0.977 \\
\hline \multirow[t]{2}{*}{ Married } & Single/divorced & $15(24.6 \%)$ & $13(24.1 \%)$ & \multirow[t]{2}{*}{0.949} \\
\hline & Married & $46(75.4 \%)$ & $41(75.9 \%)$ & \\
\hline \multirow[t]{2}{*}{ Children } & Without & $25(41.0 \%)$ & $24(44.4 \%)$ & \multirow[t]{2}{*}{0.708} \\
\hline & With & $36(59.0 \%)$ & $30(55.6 \%)$ & \\
\hline \multirow{2}{*}{$\begin{array}{l}\text { Employment } \\
\text { status }\end{array}$} & Unemployed & $15(24.6 \%)$ & $23(42.6 \%)$ & \multirow[t]{2}{*}{$0.041^{*}$} \\
\hline & Employed & $46(75.4 \%)$ & $31(57.4 \%)$ & \\
\hline \multirow[t]{4}{*}{ Education } & Elementary school & $6(9.8 \%)$ & $7(13.0 \%)$ & \multirow[t]{4}{*}{0.526} \\
\hline & High school & $24(39.3 \%)$ & $25(46.3 \%)$ & \\
\hline & Faculty & $27(44.3 \%)$ & $21(38.9 \%)$ & \\
\hline & Postacademic degree & $4(6.6 \%)$ & $1(1.9 \%)$ & \\
\hline \multirow[t]{2}{*}{ Trauma } & No significant trauma & $38(62.3 \%)$ & $29(53.7 \%)$ & \multirow[t]{2}{*}{0.351} \\
\hline & Recent head trauma & $23(37.7 \%)$ & $25(46.3 \%)$ & \\
\hline \multirow[t]{2}{*}{ Comorbidity } & None & $33(54.1 \%)$ & $36(66.7 \%)$ & \multirow[t]{2}{*}{0.170} \\
\hline & Chronic & $28(45.9 \%)$ & $18(33.3 \%)$ & \\
\hline \multicolumn{2}{|l|}{ Back scale } & $14.33 \pm 7.016$ & $16.52 \pm 6.971$ & 0.072 \\
\hline \multicolumn{2}{|c|}{ Hamilton scale } & $13.54 \pm 5.999$ & $15.13 \pm 6.653$ & 0.294 \\
\hline
\end{tabular}

Table 1.The socio-demographic characteristics of the patients with a primary brain tumor

In Table 2 level of depressive and neurological symptoms is shown for males and females according to Back and Hamilton scales. Significant gender differences was found in female patients for insomnia $(\mathrm{p}=0.000)$ and appetite disturbance $(\mathrm{p}=0.000)$ (Pearson Chi-Square Tests). 


\begin{tabular}{|c|c|c|c|c|}
\hline \multirow{2}{*}{\multicolumn{2}{|c|}{$\begin{array}{l}\text { Parameter } \\
\text { Males } \\
(n=61)\end{array}$}} & \multicolumn{2}{|c|}{ Number of patients (\%) } & \multirow{2}{*}{$\begin{array}{l}\text { Gender difference } \\
\text { p-value }\end{array}$} \\
\hline & & $\begin{array}{l}\text { Females } \\
(n=54)\end{array}$ & & \\
\hline \multirow[t]{2}{*}{ Headache } & No & $38(62.3)$ & $34(63.0)$ & \multirow[t]{2}{*}{0.941} \\
\hline & Yes & $23(37.7)$ & $20(37.0)$ & \\
\hline \multirow[t]{2}{*}{ Seizures } & No & $45(73.8)$ & $39(72.2)$ & \multirow[t]{2}{*}{0.852} \\
\hline & Yes & $16(26.2)$ & $15(27.8)$ & \\
\hline \multirow[t]{2}{*}{ Hemiparesis } & No & $28(45.9)$ & $32(59.3)$ & \multirow[t]{2}{*}{0.152} \\
\hline & Yes & $33(54.1)$ & $22(40.7)$ & \\
\hline \multirow[t]{2}{*}{ Dysphasia } & No & $45(73.8)$ & $45(83.3)$ & \multirow[t]{2}{*}{0.215} \\
\hline & Yes & $16(26.2)$ & $9(16.7)$ & \\
\hline \multirow[t]{2}{*}{ Sleep problems } & No & $40(65.6)$ & $16(29.6)$ & \multirow[t]{2}{*}{0.000} \\
\hline & Yes & $21(34.4)$ & $38(70.4)$ & \\
\hline \multirow[t]{2}{*}{ Low libido } & No & $45(73.8)$ & $32(59.3)$ & \multirow[t]{2}{*}{0.099} \\
\hline & Yes & $16(26.2)$ & $22(40.7)$ & \\
\hline \multirow[t]{2}{*}{ Low appetite } & No & $46(75.4)$ & $23(42.6)$ & \multirow[t]{2}{*}{0.000} \\
\hline & Yes & $15(24.6)$ & $31(57.4)$ & \\
\hline \multirow[t]{2}{*}{ Weight loss } & No & $49(80.3)$ & $37(68.5)$ & \multirow[t]{2}{*}{0.146} \\
\hline & Yes & $12(19.7)$ & $17(31.5)$ & \\
\hline \multirow[t]{2}{*}{ Slowness } & No & $44(72.1)$ & $42(77.8)$ & \multirow[t]{2}{*}{0.486} \\
\hline & Yes & $17(27.9)$ & $12(22.2)$ & \\
\hline \multirow[t]{2}{*}{ Memory difficulties } & No & $45(73.8)$ & $43(79.6)$ & \multirow[t]{2}{*}{0.459} \\
\hline & Yes & $16(26.2)$ & $11(20.4)$ & \\
\hline \multirow[t]{2}{*}{ Motivation difficulties } & No & $50(82.0)$ & $39(72.2)$ & \multirow[t]{2}{*}{0.212} \\
\hline & Yes & $11(18.0)$ & $15(27.8)$ & \\
\hline
\end{tabular}

Table 2. Values of depression related variables for males and females with brain tumors

When patohystological malignant potential (grade) of the brain tumor of the patients were compared separately by gender, patients had no significant differences in malignant characteristics between the tumor groups (Chi-Square Tests, $\mathrm{p}=0.201)$ (Table 3, 


\begin{tabular}{|l|l|l|}
\hline \multirow{2}{*}{ Malignancy } & \multicolumn{2}{|l|}{ Number of patients (\%) } \\
\cline { 2 - 3 } & $\begin{array}{l}\text { Males } \\
(\mathbf{n}=\mathbf{6 1})\end{array}$ & $\begin{array}{l}\text { Females } \\
(\mathbf{n}=\mathbf{5 4})\end{array}$ \\
\hline Benign & $26(42.6)$ & $32(59.3)$ \\
\hline Potential malignancy & $12(19.7)$ & $7(13.0)$ \\
\hline High malignant potential & $23(37.7)$ & $15(27.8)$ \\
\hline
\end{tabular}

Table 3. Correlation of gender difference with malignant potential of brain tumor

Neuroradiological characteristics of the brain tumor (brain edema and tumor size) were compared by gender and results showed no statistical significant difference between gender groups (Pearson Chi-Square Tests, $\mathrm{p}>0.005)$ (Table 4).

\begin{tabular}{|l|l|l|l|l|}
\hline \multirow{2}{*}{$\begin{array}{l}\text { Parameter } \\
\text { Males } \\
(\mathbf{n = 6 1 )}\end{array}$} & \multicolumn{2}{|l|}{\begin{tabular}{l} 
Number of patients (\%) \\
\cline { 3 - 4 }
\end{tabular}} & $\begin{array}{l}\text { Females } \\
(\mathbf{n = 5 4 )}\end{array}$ & \multirow{2}{*}{$\begin{array}{l}\text { Gender difference } \\
\text { p-value }\end{array}$} \\
\hline \multirow{2}{*}{ Brain edema } & No & $24(39.3)$ & $25(46.3)$ & \multirow{2}{*}{0.452} \\
\cline { 2 - 4 } & Peritumoral & $37(60.7)$ & $29(53.7)$ & \\
\hline \multirow{2}{*}{ Tumor size (cm) } & $\leq 4$ & $26(42.6)$ & $27(50.0)$ & \multirow{2}{*}{0.428} \\
\cline { 2 - 4 } & $>4$ & $35(57.4)$ & $27(50.0)$ & \multirow{2}{*}{0.97} \\
\hline \multirow{2}{*}{ Depression } & No & $43(70.5)$ & $30(55.6)$ & \\
\cline { 2 - 4 } & Yes & $18(29.5)$ & $24(44.4)$ & \\
\hline
\end{tabular}

Table 4. Correlation of gender difference with depression and neuroradiology variables

In males, a statistically significant decrease in depression was observed between pre-operative variables and those made 3 months after the operation (McNemar Test, $\mathrm{p}=0.002$ ). In addition, among males depression scores decreased significantly between pre-operative variables and those made 3 months after the operation (McNemar Test, $\mathrm{p}=0.049$ ). In female patients, as seen in Table 5., postoperative variebles showed a statistically significant decrease of depression 3 months after the operation (McNemar Test, $\mathrm{p}=0.039$ ).

\begin{tabular}{|c|c|c|c|c|c|c|c|}
\hline \multicolumn{2}{|l|}{ Parameter } & \multicolumn{6}{|c|}{ Number of patients (\%) } \\
\hline & & \multicolumn{2}{|c|}{ Males $(n=61)$} & \multicolumn{2}{|c|}{ Females $(n=54)$} & \multicolumn{2}{|c|}{ Total $(n=115)$} \\
\hline & & \multicolumn{6}{|c|}{ Initial depression } \\
\hline & & $\begin{array}{l}\text { Without } \\
(n=34)\end{array}$ & $\begin{array}{l}\text { Yes } \\
(n=27)\end{array}$ & $\begin{array}{l}\text { Without } \\
(n=22)\end{array}$ & $\begin{array}{l}\text { Yes } \\
(n=32)\end{array}$ & $\begin{array}{l}\text { Without } \\
(n=56)\end{array}$ & $\begin{array}{l}\text { Yes } \\
(n=59)\end{array}$ \\
\hline \multirow{2}{*}{$\begin{array}{l}\text { Depression } \\
\text { after } 3 \\
\text { months }\end{array}$} & no & $30(88.2)$ & $13(48.1)$ & $20(90.9)$ & $10(31.2)$ & $50(89.3)$ & $23(39.0)$ \\
\hline & yes & $4(11.8)$ & $14(51.9)$ & $2(9.1)$ & $22(68.8)$ & $6(10.7)$ & $36(61.0)$ \\
\hline \multicolumn{2}{|c|}{$\begin{array}{l}\text { Gender difference } \\
\text { p-value }\end{array}$} & \multicolumn{2}{|l|}{0.049} & \multicolumn{2}{|l|}{0.039} & \multicolumn{2}{|l|}{0.002} \\
\hline
\end{tabular}

Table 5. Correlation of initial depression and after 3 months after brain tumor operation in males and females 


\section{Discussion}

Gender difference in the level of depression has been found in other follow-up studies among patients with different somatic diseases ${ }^{[1-4]}$. Mechanisms of depression in patients with brain tumors have not been fully elucidated and numerous factors have been examined. The physiologic and functional impact of a brain tumor diagnosis may result in more specific neuropsychiatric, cognitive, and behavioral manifestations. Sexual differences on depression among brain tumor patients has been rarely studied ${ }^{[5,6]}$. Sex differences in brain and hormone levels are the structural and functional basis of sex differences in the prevalence of neuropsychiatric disorders. According to some studies, the prevalence of depression is higher in women than in men ${ }^{[8,11]}$.

The purpose of our study was to explore difference between gender and depression in patients with brain tumors. In our results, there were no statistically significant differences between gender groups and depression and level of depression according mean values of Back and Hamilton scales. Our data are not similar to the majority of results from epidemiological studies that show that depression is more prevalent in females but there is not many of them.

Gender differences show also in their symptoms and neurological signs. In some studies a neurological disease with left-hemisphere lesions, resulting in aphasia in $41 \%$ of males and $11 \%$ of females, whereas manual apraxia was found in $6 \%$ of females and $42 \%$ of males ${ }^{[11]}$. Althought, according to our results that there were no significant differences between gender groups and depression and level of depression, our results showed that females had more intensive signs of depression for insomnia and appetite difficulties.

Malignant brain tumors, are diagnosed twice as often in males, who suffer greater cognitive impairments than females and do not survive as long ${ }^{[12]}$. The researchers found that retinoblastoma protein (RB), a protein known to reduce cancer risk, is significantly less active in male brain cells than in female brain cells ${ }^{[9]}$. Our research did not show statistically significant difference between males and females in comparation with malignant potential of brain tumors like in earlier mentioned researches.

Aggressive surgery may extirpate tumor that compromises the limbic pathways and reduce the level of depression ${ }^{[12]}$. These pathways are functioning better after this surgery. Mainio et al. ${ }^{[6]}$ found that tumors in the right hemisphere of the brain are associated with anxiety and it is significantly reduced after surgery.

Our research showed that a statistically significant decrease in depression was observed between preoperative variables and those made 3 months after the operation. Among males depression scores decreased significantly between pre-operative variables and those made 3 months after the operation. In female patients, postoperative variables showed a statistically significant decrease of depression 3 months after the operation.

Lampl et al. ${ }^{[14]}$ found a statistically significant correlation between the extent of edema and the presence of psychiatric symptoms, but not between tumor size and psychiatric symptoms. The correlation between the volume of edema and psychiatric symptoms suggest that the pathophysiological mechanism of disruption intracerebral routes could be the reason for these connections, rather than a simple compressive effect of the tumor mass. Multifocal tumors and tumors larger than $4 \mathrm{~cm}$ in diameter are associated with an increased occurrence of depression ${ }^{[12]}$. How these factors affect the depression is not fully explained. There may be a frontal or limbic deficits or disinhibition resulting from the action of these tumors. Neuroradiological characteristics of the brain tumor (brain edema and tumor size) were compared by gender and results showed no statistical significant difference between gender groups.

\section{Conclusion}

Connection between gender differences in the level of depression among brain tumor patients deserves special attention in future research. Whether sex differences in the brain with brain tumor are indeed the basis for the sex difference in neuropsychiatric diseases has yet to be established. 


\section{Literature}

1. Gray LJ, Sprigg N, Bath PM, Boysen G, De Deyn PP, Leys D, et al. Sex differences in quality of life in stroke survivors: data from the Tinzaparin in Acute Ischaemic Stroke Trial (TAIST). Stroke 2007; 38: 2960-2964.PMID: 17901387

2. Heinonen H, Volin L, Uutela A, Zevon M, Barrick C, Ruutu T. Gender-associated differences in the quality of life after allogeneic BMT. Bone Marrow Transplant 2001; 28: 503-509.PMID: 11593325

3. Holzner B, Kemmler G, Kopp M, Nguyen-Van-Tam D, Sperner-Unterweger B, Greil R. Quality of life of patients with chronic lymphocytic leukemia: results of a longitudinal investigation over 1 year. Eur J Haematol 2004;72(6):3819.PMID: 15128416

4. Emery CF, Frid DJ, Engebretson TO, Alonzo AA, Fish A, Ferketich AK et al. Gender differences in quality of life among cardiac patients. Psychosom Med 2004; 66: 190- 197.PMID: 15039503

5. Price TRP, Goetz KL, Lovell MR. Neuropsychiatric aspects of brain tumors. In: Kaplan HI, Sadock BJ, editoris. Kaplan and Sadocks compenhensive textbook of psychiatry. 9th ed. Philadelphia: Wolters Kluwer; 2009. p. 435541.ISBN-13: 978-0781773270

6. Mainio A, Hakko H, Niemelä A, Koivukangas J, Räsänen P. Depression in relation to anxiety, obsessionality and phobia among neurosurgical patients with a primary brain tumor: a 1-year follow-up study: Clin Neurol Neurosurg 2011 Oct; 113(8) : 649-53.doi: 10.1016/j.clineuro.2011.05.006. Epub 2011 Jun 12. PubMed PMID:21664761

7. Weitzner MA, Meyers CA, Byrne K. Psychosocial functioning and quality of life in patients with primary brain tumors. J Neurosurg 1996;84:29-34.PMID: 8613832

8. Ferlay J, Shin HR, Bray F, Forman D, Mathers C, Parkin DM. Estimates of worldwide burden of cancer in 2008: GLOBOCAN 2008. Int J Cancer. 2010 Dec 15;127(12):2893-917. doi: 10.1002/ijc.25516. PubMed PMID: 21351269.

9. Pringle AM, Taylor R, Whittle IR. Anxiety and depression in patients with an intracranial neoplasm before and after tumour surgery. Br J Neurosurg. 1999 Feb; 13(1):46-51PMID: 10492684

10. Sintonen H. The 15D instrument of health-related quality of life: properties and applications. Ann Med 2001; 33: 328-336. PMID:11491191

11. Mainio A, Hakko H, Niemelä A, Koivukangas J, Räsänen P. Gender difference in relation to depression and quality of life among patients with a primary brain tumor. Eur Psychiatry 2006; 21: 194-199.PMID:16140507

12. Litofsky NS, Farace E, Anderson F, Meyers CA, Huang W, Laws ER. Glioma Outcomes Project Investigators. Depression in patients with high grade glioma: results of the glioma outcomes project. Neurosurgery 2004; 54:358 367. PMID: 14744282

13. Sun T, Warrington NM, Luo J, Brooks MD, Dahiya S, Snyder SC et al. Sexually dimorphic RB inactivation underlies mesenchymal glioblastoma prevalence in males.J Clin Invest. 2014 Sep;124(9):4123-33. doi: 10.1172/JCI71048 PMID: 25083989

14. Lampl Y, Barak Y, Achiron A, Sarova-Pinchas I. Intracranial meningiomas: correlation of peritumoral edema and psychiatric disturbances. Psychiatry Res. 1995 Sep 29; 58(2): 177-80.PMID: 8570771 